\title{
Using Circles to Cope with the Eruption of Volcán de Fuego in Guatemala
}

Miguel TELLO, Flor GARCíA

\section{ABSTRACT}

On June 3, 2018, the Volcán de Fuego (Fire Volcano) in Guatemala erupted, killing 300 people and leaving close to 2,000 homeless and relocated to temporary shelters. Lava flows buried the towns of Alotenango and San Miguel Los Lotes; El Rodeo was also highly impacted.

The government, nongovernmental organizations (NGOs) and international response was focused on relocating villagers to safe locations and providing health care, medicines and food, as well as initiating a formal plan to move entire communities that would not be able to

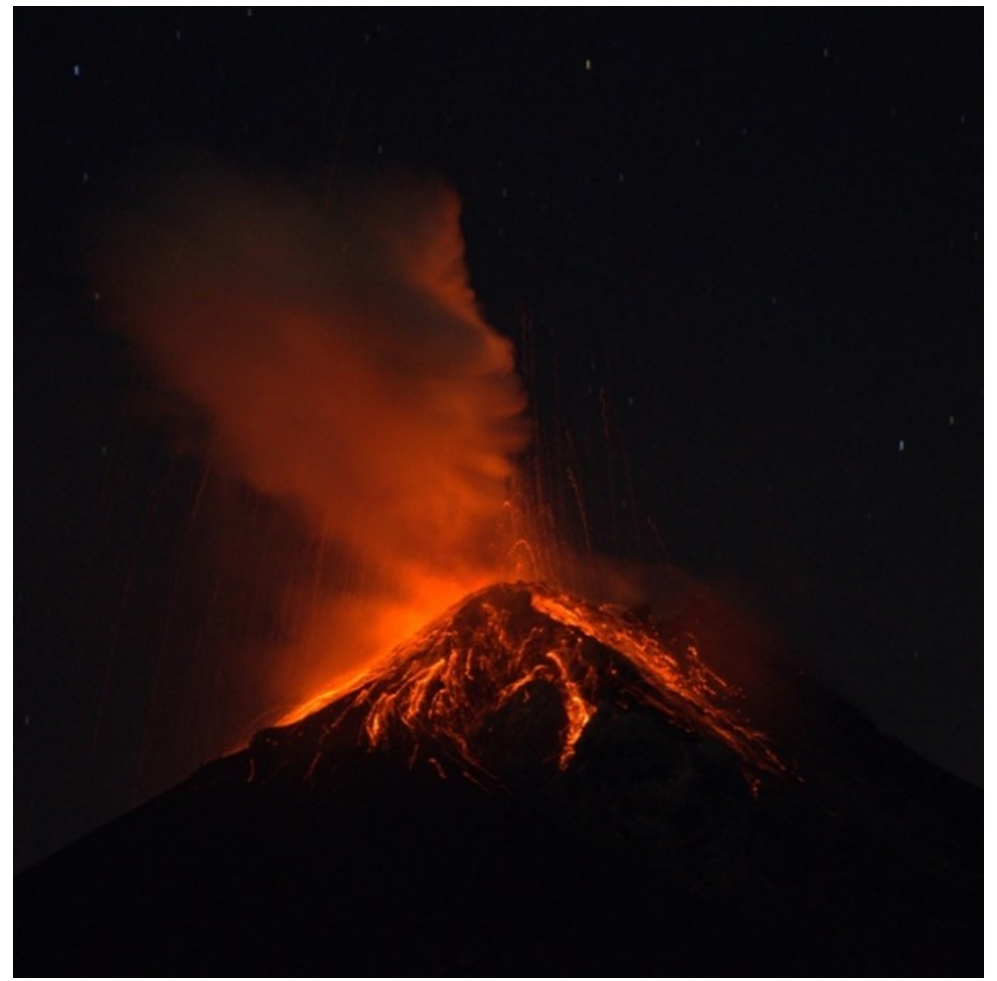

Volcán de Fuego Eruption (2017)

\section{Authors}

\section{MIGUEL TELLO}

The Strachan Foundation Executive Director

International Institute for Restorative Practices Adjunct Professor

\section{FLOR GARCIA}

Asociación de Liderazgo en Guatemala

Executive Director

International Institute for Restorative Practices Board Member live in those high-risk areas again.

However, the emergency response made no effort to listen to the people affected by the eruption or to provide them with a space where they could find emotional support and release some of the emotions around the trauma they suffered. Asociación para el Liderazgo en Guatemala (ALG), a local NGO that trains other NGO leaders in the country, offered an intervention that provided a space for both people displaced by the eruption and emergency response teams to find support in the use of restorative circles. This article will examine ALG's intervention and offer some lessons learned about providing circles to people affected by natural disaster, and how they can be helpful in coping with the aftermath of such a traumatic event. 


\section{RESUMEN}

El 3 de junio del 2018 el Volcán de Fuego en Guatemala hizo erupción matando a 300 personas y dejando a cerca de 2,000 personas sin casa y ubicados en refugios temporales. El flujo de lava soterró a las comunidades de Alotenango y San Miguel Los Lotes. El Rodeo también fue impactado.

El gobierno, las ONGs y la respuesta internacional se enfocó en reubicar a los miembros de las comunidades a localidades seguras y proveerles atención médica, medicinas y comida. También se enfocaron en crear un plan para reubicar a las comunidades que no podrían continuar viviendo en áreas de alto riesgo.

Sin embargo, la respuesta de emergencia no hizo ningún esfuerzo por escuchar a las personas afectadas por la erupción ni proveerles un espacio donde pudieran encontrar apoyo emocional y expresar las emociones en torno al trauma que habían sufrido. Asociación para el Liderazgo en Guatemala (ALG) una ONG local que capacita a líderes de ONG en el país, ofreció una intervención que ofreció un espacio tanto para personas desplazadas como para los equipos de respuesta de emergencia para que recibieran apoyo a través de círculos de diálogo. Este artículo examinará la intervención de ALG y ofrecerá algunas lecciones aprendidas acerca de ofrecer círculos para personas afectadas por un desastre natural y como esto puede ayudar a enfrentar las secuelas de un evento tan traumático.

Keywords: circles, restorative practices, trauma, natural disasters, community empowerment

\section{ERUPTION OF THE VOLCÁN DE FUEGO}

On the morning of Sunday, June 3, 2018, the Volcán de Fuego (Fire Volcano) in Guatemala began its second eruptive phase of the year. A cloud came out of the crater and soon covered the sky with ash and volcanic material five centimeters in diameter that impacted hard as it fell. Noon turned dark as night, and rumbling could be heard miles away. The destructive pyroclastic flow of lava, hot ash and sand rapidly reached several communities, burning and burying everything in its path. Entire families were trapped, unable to get out; others cried and fled in desperation, running for help. The eruption killed 300 people and left about 2,000 homeless and relocated to temporary shelters. Lava flows buried the towns of Alotenango and San Miguel Los Lotes; El Rodeo was also highly impacted.
Wholeness does not mean perfection; it means embracing brokenness as an integral part of life.

-Parker J. Palmer, A Hidden Wholeness

Guatemala is a small country located in Central America, bordering Mexico and Belize to the North and Honduras and El Salvador to the South. It has three major regions: the highlands, where two mountain chains cross Guatemala from west to east, the Pacific coast south of the mountains, and the Petén region north of the mountains. The country has 37 volcanos, four of which are active: Volcán de Fuego, Santiaguito, Tacaná and Pacaya.

\section{EMERGENCY RESPONSE}

The government was highly disorganized and unprepared to respond to the crisis. When the 
administration of President Jimmy Morales took over the emergency response office in 2016, they removed the incumbent national emergency response coordinator and his technical team and appointed a new team. When the eruption occurred, the newly-appointed team did not have the capacity to develop a coherent plan. One concrete action that the government did take was to enable many temporary shelters in schools and churches in towns that were close by, but safe.

Non-governmental organizations (NGOs) and civil society concentrated their efforts on providing food and clothing and offering entertainment for children. However, since there were no protocols, the number of people who came to help and brought sweets, piñatas, etc., was overwhelming. Some NGOs established teams to monitor and guarantee people's safety. International solidarity was manifested with funds, donations of supplies and medicines, and with specialized groups that came from Mexico and the United States to continue the search and rescue of survivors and recovery of bodies at the scene of the tragedy. The Pan American Health Organization guided the government with protocols and personalized advice for local officials.

Guatemala is a high-risk country for all kinds of natural disasters. Multiple studies have warned about the vulnerability of the country and yet the state has taken few steps to mitigate the inherent risk. Experts of the Instituto de Investigación y Proyección sobre Ambiente Natural y Sociedad at the Rafael Landivar University (Institute for the Research and Projection of the Natural Environment and Society) mention that every time there is a catastrophe the "lack of commitment and political will of the government" are evidenced (García \& Mejía, 2018). Brannum and Watts (2020) describe how the emergency response of the Volcan de Fuego eruption was carried out mostly by a group of volunteer firemen who receive little funding from the federal government although they are closely connected to the local government. The authors also mention a deep-seated distrust of government mentioning that people who collected goods for

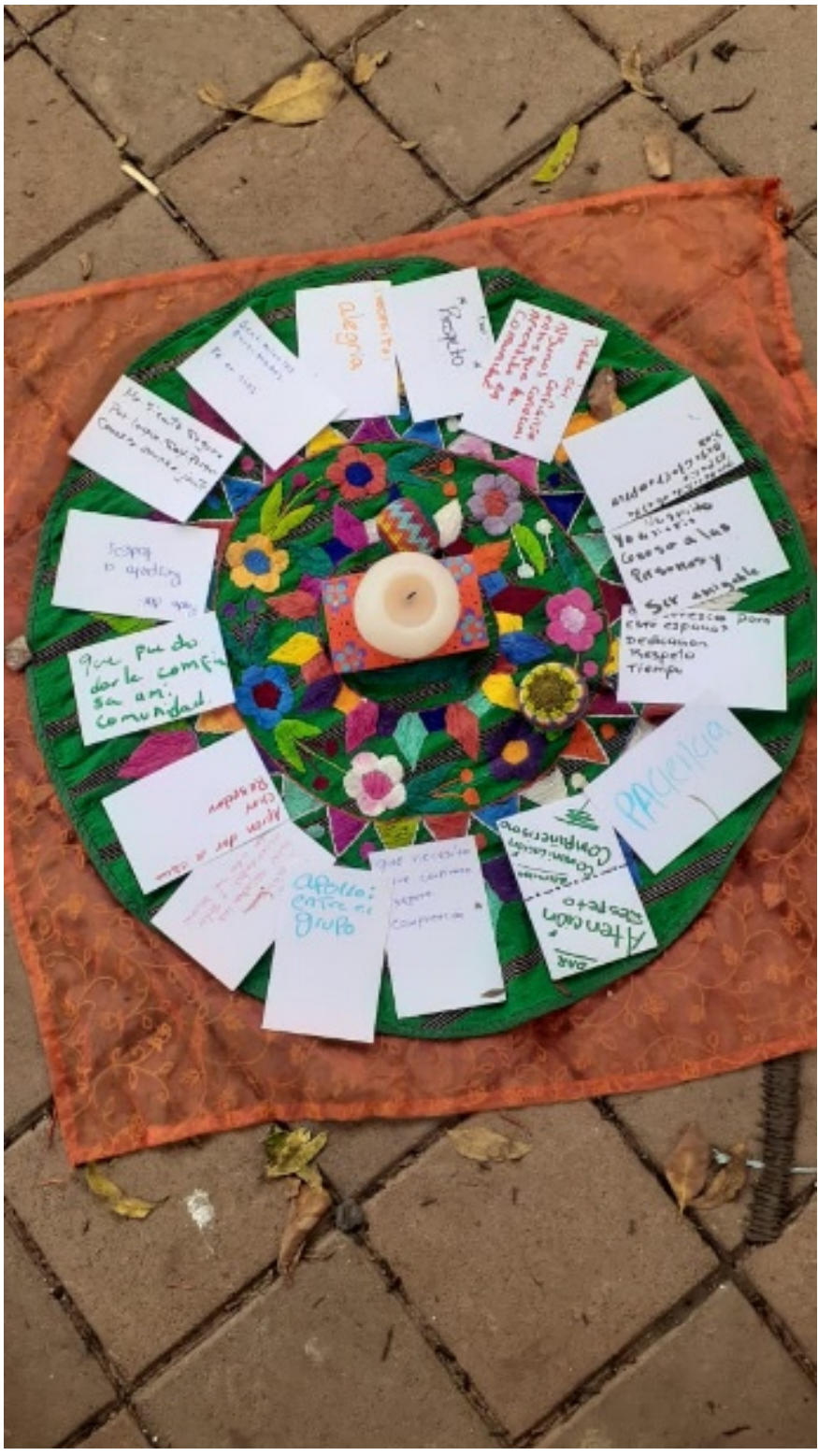

Circle centerpiece during circle for people displaced by the Volcán de Fuego eruption (2018).

distribution for the affected families would bring the goods to non-state actors because they believed the donations would actually get to the people in need.

\section{ASOCIACIÓN DE LIDERAZGO GUATEMALA (ALG)}

ALG is a non-profit organization that offers transformational processes to increase the positive impact of leaders in Central America. 
They provide leadership training that includes management tools and experiences grounded in a deep review of personal purpose and emphasizes the importance of collaboration between leaders and organizations. ALG practices what it preaches: everything they do, whether it is a training, a more formal course, or a staff meeting always starts with a Circle of Trust, a methodology created by Parker Palmer that has been a common thread in ALG's work since its founding in 2012. Later, when learning about the Restorative Practices movement and the International Institute for Restorative Practices [IIRP], it seemed to ALG like a natural fit to integrate other ways of implementing circles.

IIRP provided ALG with a theoretical and methodological framework to emphasize Restorative Practices as an effective means for community building and conflict resolution for leaders. Now the staff is certified to offer IIRP basic trainings. The effect is expansive, as leaders soon begin to use the circles in their organizations and communities and in general gain a clearer understanding of what it means to act and lead from a restorative point of view.

In addition to using restorative practices, ALG uses a series of social technologies that leverage small- and large-group dialogue and learning through facilitating exercises such as World Café and Open Space ${ }^{1}$. Although these methodologies are different, they also are built on the "fundamental unifying hypothesis of restorative practices," as articulated by Wachtel (2016), that "human beings are happier, more cooperative and productive, and more likely to make positive changes in their behavior when those in authority

\footnotetext{
1 In a World Café exercise, a small group of participants initially sit at various tables with a facilitator at each table. The people gathered at the table are invited to contribute their thoughts to a particular topic or questions. After ten minutes, participants are asked to move to the next table, where they will receive a summary of the previous group and add their own comments to the conversation. At the end of the exercise the facilitators summarize the findings
}

do things with them, rather than to them or for them."

ALG and the authors of this article believe in empowering local leaders and communities to respond to their context. We are conscious of the high level of inequality and discrimination that exists in Guatemalan society and are committed to building the capacity of leaders to be a voice for their own communities.

\section{CIRCLES}

The use of circles for managing conflict within groups is an ancient tradition of many indigenous communities around the world. Since the advent of the Restorative Justice movement in the 1970s, circles have become part of the means of addressing harm and strengthening community in non-indigenous Western society as well.

According to Pranis, "Circles have been used by small groups of non-indigenous people for over 30 years.” (Pranis, 2014, p. 7) In her words:

A Peacemaking Circle is a way of bringing people together in which: everyone is respected, everyone gets a chance to talk without interruption, participants explain themselves by telling their stories, everyone is equal - no person is more important than anyone else, spiritual and emotional aspects of individual experience are welcomed. (Pranis, 2014, p. 7)

There are a wide variety of circles and applications. Some of the most common types are listening circles, talking circles, support circles, and celebration circles. The type of circle that ALG used to address the concerns of community

at each table. In an Open Space exercise, participants are asked to choose several topics to be discussed and choose a leader for the topic. They are then asked to move to the topic they wish to address. They may stay with a single topic or move to several topics. At the end of the discussion, leaders share the findings with the whole group. 
members and emergency response staff members is called a responsive circle.

In a circle, the participants are seated in a round formation so that everyone can see and hear each other clearly. The facilitator uses a talking piece that is passed to each person sequentially to indicate whose turn it is to speak; only the person holding the talking piece may speak, while everyone else listens. The facilitator's roles are (a) to offer questions for the group to respond to, and (b) to maintain a safe and respectful environment for all participants.

\section{CIRCLES GIVE VOICE TO THE COMMUNITY}

Pranis, et al. (2003) describe the holistic nature of circles, in which they "...include all interests in order to find, workable, healing solutions," (p. 63) and how they "...take a holistic approach by drawing on our whole being: physical, mental, emotional and spiritual" (p. 63). This approach is indispensable for interventions that offer support to communities affected by a natural disaster.

An academic approach to a natural disaster or other community harm can have a blind spot: It considers that it has the correct and best answer to whatever the situation is at hand. This usually does not fit with the lived experience of community members. It also compartmentalizes responses to a physical or mental approach, leaving out the emotional and spiritual aspects of human beings. Circles are powerful because they employ the holistic approach described by Pranis et al. (2003).

In their work training leaders in Central America, ALG identifies and leverages the wisdom that is already present in communities. ALG employs circles as a way for this wisdom, and the diverse voices of a variety of community members, to emerge. This is especially important in

\footnotetext{
2 The emerging social science of Restorative Practices is the larger discipline under which these practices are
}

\section{An academic approach to a natural disaster or other community harm can have a blind spot: It considers that it has the correct and best answer to whatever the situation is at hand. This usually does not fit with the lived experience of community members.}

Guatemala, where the voices of women are often silent.

\section{WHY ALG CHOSE TO USE RESPONSIVE CIRCLES}

ALG quickly realized that the people that had lost their homes and loved ones during the eruption of the Volcán de Fuego had a variety of emotional needs and concerns. ALG staff members chose to use responsive circles, where participants are asked to respond to questions brought by the facilitator. These questions help the participants to reflect on what their experience has been and how it has affected them. It also helps circle participants to look for ways in which they can offer support to one another, or to find the support they need from others.

\section{RESTORATIVE PRACTICES AND TRAUMA}

There are many sources of trauma in people's lives; it can be triggered by physical or psychological harm. For many years, Restorative Justice has been implemented successfully to deal with situations where someone harms another person. Circles and restorative conferences are two of the main ways in which harm is addressed in Restorative Justice and Restorative Practices ${ }^{2}$. However, whereas in Restorative Justice settings, circles would be used to address harm, responsive circles such as the ones used by ALG seek to leverage dialogue and learning.

Trauma plays an important role in the reactions of people who have been affected by a natural disaster. There is a substantial body of literature

applied in many fields. A subset of Restorative Practices in criminal justice is Restorative Justice. 
on the neuroscience of trauma and its long-term effects on people. Levine (2015) and Siegel (2013) are among the authors who have written about the way in which the fight-or-flight response is activated in a traumatic event, and how the hippocampus and amygdala in the brain respond. Rundell et al. (2018) also make a connection between trauma and Restorative Practices in a study of trauma and refugees; they write:

The authors suggest the use of restorative approaches as a way to address the trauma and harm experienced by refugees to release their traumatic memories and allow the joy of living. Restorative approaches have the and others in a relationship. (Rundell et al., 2018, p. 20, 21)

Rundell et al. (2018) also cite Weingarten (2003) and her work around witnessing, a process that involves the person who has suffered trauma being able to articulate their experience and then receiving feedback from observers who are tasked with listening attentively and expressing how they empathize with that person. The facilitator of a witnessing process then asks the person who has suffered trauma to respond to what the listeners have said. The witnessing process is very helpful in being able to change the narrative that the person suffering from trauma has embodied. Weingarten (2003) posits four witnessing windows on a graph of levels of awareness/unawareness and levels of empowerment/disempowerment as shown in Figure 1.

Rundell et al. (2018) explain how the ideal is to be in Window 1 , where participants witness in a restorative way where they are both aware and empowered. In Window 2, where witnesses are empowered but unaware, leads to "malpractice, abuse and/or bullying" (2018). Window 3 is labeled neglectful-dismissive, where witnesses are disempowered and unaware "leads to helplessness," a state often experienced by

\section{Figure 1}

Weingarten's Witness Positions

\begin{tabular}{|c|c|c|}
\cline { 2 - 3 } \multicolumn{1}{c|}{} & Aware & Unaware \\
\hline Empowered & $\begin{array}{c}\mathbf{1} \\
\text { Reclaiming } \\
\text { Restorative }\end{array}$ & $\begin{array}{c}\mathbf{2} \\
\text { Coercive } \\
\text { Manipulative }\end{array}$ \\
\hline Disempowered & Permissive & $\mathbf{3}$ \\
& & $\begin{array}{c}\text { Neglectful } \\
\text { Dismissive }\end{array}$ \\
\hline
\end{tabular}

Reprinted from "Managing trauma: A restorative process" by Rundell, F. C., Sheety, A., \& Negrea, V., 2018, In E. Sengupta \& P. Blessinger (Eds.), Refugee education: Integration and acceptance of refugees in mainstream society (pp. 17-31). Emerald Publishing. doi: 10.1108/S2055-364120180000011004 
refugees. The fourth window of disempowerment and awareness takes place when "refugees arriving in a new country often become aware of the privileges around them, yet identify restrictions within themselves, as a result of language, cultural, discrepancies, or skill deficiencies" (Weingarten, 2003, as cited in Rundell et al., 2018).

As we will demonstrate, the work of ALG focused on offering survivors of the volcanic eruption a restorative witnessing that would empower the community and help them to be aware of the internal resources they have to address the traumas they experienced after the disaster.

\section{ALG INTERVENTIONS}

\section{Facilitating a Circle at a Temporary Shelter}

When ALG heard the news about the eruption, they decided they had to do something to offer support to the people that had been displaced by the Volcán de Fuego eruption. What better than to offer circles where the participants could express how they had been affected and how they could offer support to one another? Flor García, Executive Director of ALG, describes her experience facilitating the first circle:

In a forgotten street of Escuintla, behind the bus terminal, a dirty and improvised market emerges full of people and dogs in the midst of a suffocating heat. There we found the entrance to a school that had been converted into a temporary shelter. It had been a week since the eruption, and we had made a first and frustrating visit to another shelter some days ago. This time it would be different, we were told, because the shelter coordinator would be there waiting for us, she will have prepared a space, and people would have been invited to participate. When we got there, we heard that the coordinator was not there, and that no one was in charge. Dozens of people were milling in the patio,

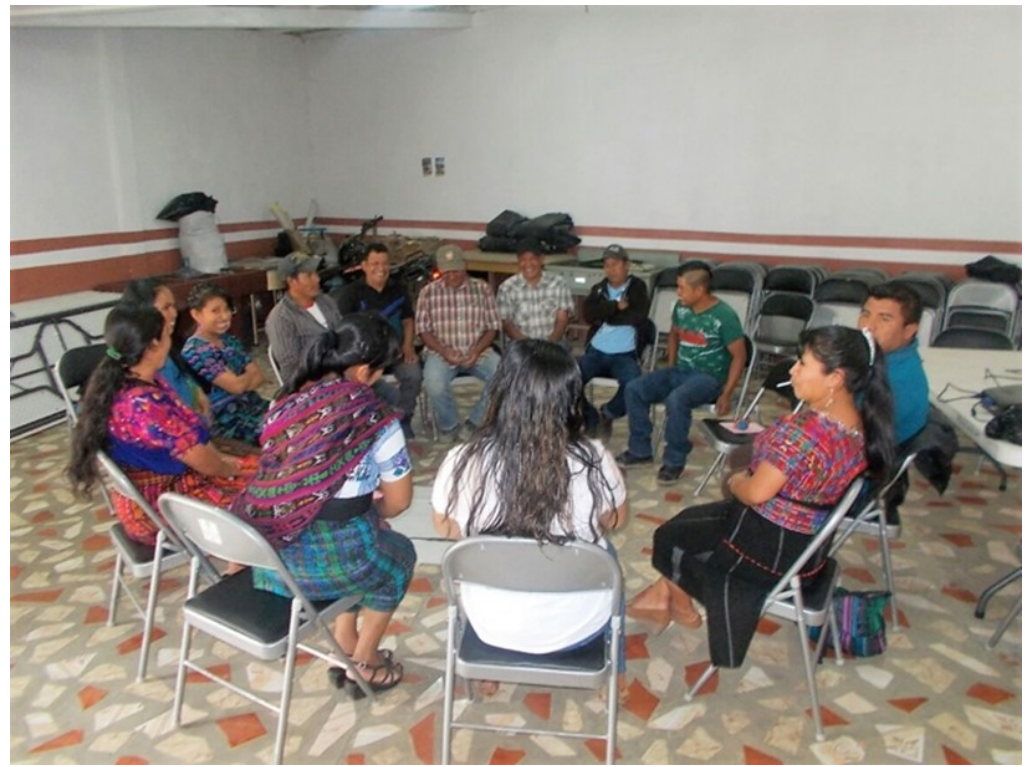

Circle with community leaders (2018).

some sat lethargically inside the small classrooms full of mattresses with mountains of clothes and dirty dishes. Some parents were leaving hastily to take their children to a school still functioning nearby. (F. García, personal communication, April 2020)

After identifying some of the community leaders at the shelter, García and her colleague, Yaneth Garces, were able to convene a circle with about 15 people. After explaining the use of the talking piece and how the circle would function, the facilitators asked the participants to say their name and one thing they were grateful for. García describes what happened next:

The powerful effect of seeing and listening to one another was immediate. In the midst of the noise of the impoverished shelter, a space of silence was created. We saw people lean in, eyes slightly closed to hear better. We heard men and women speak about their gratitude for life, for food, the solidarity of a neighbor, for the priest who came to offer Mass, because although they lost their homes, they still had hope. 
After that came the stories. "Did you ever experience a very difficult situation where it was hard to think that things could get better, but they finally did?" They spoke and listened, assenting with their heads, with tears in their eyes, speaking of other places, other times, acknowledging their own resilience and being nourished by others. Towards the end of the circle, participants expressed how they could offer support to one another and what they could do to make this time more agreeable. (F. García, personal communication, April 2020)

When the facilitators returned to the shelter later on, all the people had been relocated to other shelters.

\section{Listening to Emergency Response Workers}

Sara Hurtarte and Anigail Quic, directors of SERES, an NGO working directly with the communities affected by the eruption, knew that their team was experiencing burnout after two weeks of non-stop intervention. They contacted ALG to request support for their team. Lucy Estacuy, an ALG staff member, along with the executive director, facilitated a circle for the team using IIRP's restorative question wallet cards ALG staff describe their experience with the circle:

We realized that what was most difficult for them was not the horrors of the zone where they were working each day, nor the stories from families dealing with grief. It was their own needs, missing their families, and the weight of the protective mask they had to put on day after day in order to continue helping. The circle was a space for the emergency workers to be heard without judgment, a space where their voice could be expressed. (F. García, personal communication, April 2020)

ALG next met with various organizations, government agencies and representatives of the World Health Organization. A question ALG kept
Responses are needed that empower and give voice to those who have been directly affected. This is where circles can be so powerful, as shown by the experience of ALG. People need to be able to tell their stories in a safe environment, connect with one another, and offer one another support.

raising was "Where is the voice of those displaced by the eruption?" No one seemed to have an answer. ALG became part of a committee to create a response plan that would focus on socialemotional well-being. The experience was very frustrating for ALG, since the lengthy meetings resulted in an official document, but yielded no other tangible results.

After eight months of attempting to bring Restorative Practices and circles to the people affected by the eruption through official channels, ALG decided to do what it does best: Work directly with the community. ALG contacted SERES, partnered with them, and together started offering Restorative Practices training to community leaders. The training took place under a tree in front of the shelters. According to García,

Lucy Estacuy, Bekah Giacomantonio and I always started with a circle and the agreements for how we would share this time together, and then we would spend time sharing key ideas of Restorative Practices using elements of popular education.

The participants often seemed absent; their facial expressions not easily interpreted, nor did they speak very much. Sometimes we went back home frustrated, wondering whether we had reached them. But, the following week, they would tell us how they had started to use affective statements to communicate with their families and neighbors, and then we would reaffirm that we always need to trust in the process. I was reminded of one of Parker Palmer's quotes: "Know that it's possible to leave the circle without 
whatever it was that you needed when you arrived, and that the seeds planted here can keep growing in the days ahead." (F. García, personal communication, April 2020)

For four weeks, ALG worked with the community leaders and trained them to facilitate circles. They all thirsted for restoration, and ALG provided the basic elements for the community members to start listening to one another and to start healing from the terrible tragedy they had lived through.

ALG staff interviewed several community leaders from Los Lotes, one of the most affected communities by the eruption, to listen to their experience of restorative practices after families had been settled in simple government housing. Ana María mentioned that "new interest in leadership emerged, greater courage, and thought the experience and learning (restorative practices) we had was very beneficial" (L. Estacuy, personal communication, November 23, 2020). Steven Mijongos, a youth leader, mentioned that "working with youth has been easier than working with adults, with youth dialogue tends to be more focused on inquiry, they repress some emotion, but in general they speak from the self and express feelings allowing me to connect with them" (L. Estacuy, personal communication, November 23, 2020). Ana María also describes how circles have helped their community to deal with situations. She mentions that they were able to use circles to address a situation in Las Palmas where people were dumping garbage in a small river. Ana María mentions: "We had a dialogue and I feel that it worked because the problem was addressed" (L. Estacuy, personal communication, November 23, 2020).

\section{LESSONS LEARNED}

\section{Listening to the emotional needs of people affected by tragedy}

In emergency responses such as the one offered to the people displaced by the eruption of the Volcán de Fuego, addressing the immediate physical needs of those affected is paramount. However, once these immediate needs are met, it is equally important to address their emotional needs as well. Although the local universities and the Guatemalan Guild of Psychologists sought to address these needs by offering psychological counseling, this was not effective because sessions were offered on a single time basis with no follow up. Similar patterns have been repeated in previous natural disasters. An example of this is the mudslide that took place in El Cambray in the municipality of Santa Catarina Pinula on October 1,2015 . The mudslide buried more than two hundred houses and killed 280 people. La Prensa Libre newspaper reported how volunteers tried to help children deal with trauma by bringing candy and piñatas. The newspaper reported that the park of Santa Catarina Pinula became "a fleeting center of happiness” (Rojas \& Gramajo, 2015).

Responses are needed that empower and give voice to those who have been directly affected. This is where circles can be so powerful, as shown by the experience of ALG. People need to be able to tell their stories in a safe environment, connect with one another, and offer one another support.

\section{The power of involving local community leaders}

Communities have strengths of their own, and these can be accessed through their leaders. One of the things that ALG learned was the importance of working with local leaders in order to reach the community. This has the effect of having a more direct contact with the community, rather than waiting for external actors to come in. As Wachtel (2016) writes, "doing things with people, instead of for them or to them" is crucial to their empowerment. It is also the most sustainable approach to change and healing.

\section{"Fixing" or "helping" can impede community empowerment and healing}

In her article, "Helping, Fixing or Serving?" Rachel Naomi Bremen (2017) writes: 
Fixing and helping create a distance between people, but we cannot serve at a distance. We can only serve that to which we are profoundly connected. Helping, fixing and serving represent three different ways of seeing life. When you help, you see life as weak. When you fix, you see life as broken. When you serve, you see life as a whole. Fixing and helping may be the work of the ego, and service the work of the soul. (Bremen, 2017, para. 1)

The government agencies, universities and many NGOs sought to "help" or "fix" the people displaced by the Volcán de Fuego. They acted from a perspective of pity. ALG sought to serve the community of people displaced by the eruption. They realized that a humble stance is required for this approach, and that the community has its own internal resources that can be tapped when a facilitator is available to provide a safe space and help the community to articulate its own voice.

Natural disasters have always been, and will continue to be, a part of human existence. Before we became highly specialized and professionalized, when a community suffered a natural disaster, people would come together and find ways to address the situation. This is not to say that addressing the physical needs of a community in the aftermath of a natural disaster is not important; however, it is equally essential to help a community find its voice and use the internal resources it has at its disposal. Circles can provide that space.

\section{"Helping" or "fixing" approaches as responses to natural disasters are limiting. They do not empower communities or attend to emotional and spiritual needs.}

\section{Trusting in the circle process}

One of the things ALG found in working with the communities affected by the eruption of the Volcán de Fuego is that trauma could prevent them from expressing their feelings openly. However, trusting the circle process has been key. As previously described, ALG staff members had to let go of any expectations they had for the circle process. To their surprise, even though it sometimes felt like the participants were not fully engaged, they later demonstrated that the circle had influenced the way they related to one another. This was especially visible by the way the community members continued to use circles on their own.

\section{CONCLUSIONS}

"Helping" or "fixing" approaches as responses to natural disasters are limiting. They do not empower communities or attend to emotional and spiritual needs. Circles, on the other hand, place the wisdom of the community front and center. This requires facilitators to adopt a humble stance, one where they are accompanying the process rather than being protagonists. This stance contributes to the empowerment and healing of communities affected by natural disaster. 


\section{REFERENCES}

Brannum, K. \& Watts, M. (2020, March 9). Emergency response in developing countries: The case of Guatemala. Public Safety. https://inpublicsafety.com/2020/03/emergency-response-indeveloping-countries-the-case-of-guatemala/

García, A. \& Mejía, D. (2018, June 28). Guatemala está expuesta a toda clase de desastres, excepto a tormentas de nieve (por el momento). Plaza Pública.

https://www.plazapublica.com.gt/content/guatemala-esta-expuesta-toda-clase-de-desastresexcepto-tormentas-de-nieve-por-el-momento

International Institute for Restorative Practices. (n.d.). Restorative questions cards. https://store.iirp.edu/restorative-questions-cards-pack-of-100-english-or-spanish/

Levine, P. A. (2015). Trauma and memory: Brain and body in a search for the living past. North Atlantic Books.

Palmer, P. J. (2004). A hidden wholeness: The journey toward an undivided life. Jossey-Bass.

Pranis, K. (2014). The little book of circle processes: A new/old approach to peacemaking. Good Books.

Pranis, K., Stuart, B. \& Wedge, M. (2003). Peacemaking circles: From crime to community. Living Justice Press.

Remen, R. N. (2017, August 6). Helping, fixing or serving? Lion's Roar. https://www.lionsroar.com/helping-fixing-or-serving/

Rojas, A. \& Gramajo, J. (2015, October 17). Niños de El Cambray 2 intentan superar la tragedia. Prensa Libre. https://www.prensalibre.com

Rundell, F. C., Sheety, A., \& Negrea, V. (2018). Managing trauma: A restorative process. In E. Sengupta \& P. Blessinger (Eds.), Refugee education: Integration and acceptance of refugees in mainstream society (pp. 17-31). Emerald Publishing. https://doi.org/10.1108/S2055364120180000011004

Siegel, D. J. (2013). Brainstorm: The power and purpose of the teenage brain. Tarcher/Penguin Group.

Wachtel, T. (2016). Defining restorative. https://www.iirp.edu/images/pdf/DefiningRestorative_Nov-2016.pdf

Weingarten, K. (2003). Common shock: Witnessing violence every day: How we are harmed, how we can heal. Dutton/Penguin Books. 